\title{
PEMANFAATAN DATA HIDRO OSEANOGRAFI DAN BATIMETRI UNTUK PENATAAN PANTAI TATAPAAN, MINAHASA SELATAN
}

\author{
Maxi Tendean $^{1}$, Agnes Tenly Moningkey ${ }^{2}$, Joyce Christian Kumaat ${ }^{3}$ \\ ${ }^{1,2,3}$ Program Studi Geografi, Fakultas Ilmu Sosial, Universitas Negeri Manado \\ e-mail: joykekumaat@unima.ac.id \\ (1) orcid.org/0000-0002-1259-4884
}

\begin{abstract}
Critical to the management of the coastal area, drawn by destroying almost most of its right coastal area and also existence, form unfolds its nature. The purpose of this study is to examine the physical parameters of hydro-oceanography and bathymetry in the waters of the Tatapaan coast. From the result of research, surface current distribution has speed $0.01-0.9 \mathrm{~m} / \mathrm{sec}$ in twenty samples. While the maximum current $\left(u_{\text {max }}\right)$ measured at deepness $0.8 d$ is equal to $0.60 \mathrm{~m} / \mathrm{sec}$. Starting now, tidal type from a result of tidal harmonic analysis during 15 days observation shown by the ratio of Formzahl is 0.40 interpreted as the semi-diurnal tide, which is one day there are twice high water and twice low tide. Furthermore, information about bathymetric survey at Tatapaan beach, deepness variation shown with coastal morphology identified from 48 profiles follow the example of steep and sloping coast.
\end{abstract}

Keywords: : Coastal, Harmonic, Formzahl, Bathymetri, Morphology

\begin{abstract}
Abstrak: Penting untuk pengelolaan wilayah pesisir, ditarik dengan menghancurkan hampir sebagian besar wilayah pesisir yang tepat dan juga eksistensi, bentuk terbentang sifatnya. Tujuan dari penelitian ini adalah mengkaji parameter fisik hidro-oseanografi dan bathimetri perairan pantai Tatapaan. Dari hasil penelitian, distribusi arus permukaan memiliki kecepatan 0,01-0,9 m/detik dalam duapuluh sampel pengamatan. Sedangkan arus maksimum $\left(\mathrm{U}_{\max }\right)$ diukur pada kedalaman $0.8 \mathrm{~d}$ sama dengan $0,60 \mathrm{~m} /$ detik. Mulai sekarang, tipe pasang surut dari hasil analisis harmonik pasang surut selama 15 hari pengamatan ditunjukkan oleh nisbah Formzahl yaitu 0,40 diartikan sebagai pasang surut semi-diurnal, yaitu satu hari ada dua kali air tinggi dan dua kali air surut. Selain itu, informasi tentang survei batimetri di pantai Tatapaan, variasi kedalaman ditunjukkan dengan morfologi pantai yang diidentifikasi dari 48 profil mengikuti contoh pantai curam dan miring.
\end{abstract}

Kata Kunci: Pesisir, Harmonik, Formzahl, Batimetri, Morfologi

\section{PENDAHULUAN}

Sumberdaya wilayah pesisir dan pulaupulau kecil (A. Pratikto, 2003) salah satu ekosistem penting dan menjadi penyeimbang seperti hutan mangrove, terumbu karang, dan padang lamun dan estuaria (Mujio, 2016), disisi yang lain daerah aliran sungai (Sudaryono, 2002), memberikan kontribusi terjadinya penumpukan sedimen di muara sungai, sehingga wilayah pesisir ini menjadi sangat rentan terjadap kerusakan (Paimin, Pramono, Purwanto, \& Indrawati, 2012; Rahayu, Piarsa, \& Buana, 2016).

Pembangunan berkelanjutan (sustainable development) membutuhkan manajemen pengelolaan sumberdaya alam yang saling terhubung, salah satu aspek lingkungan yang penting untuk di ketahui agar pengelolaan sumberdaya dapat dilaksanakan dengan tepat adalah dengan memahami dinamika perairan. Dinamika perairan, disebabkan karena perairan berwujud fluida dan tidak mengenal batas administrasi atau ekologi, sehingga jika diperairan disuatu lokasi tercemar maka dampaknya akan tersebar di wilayah sekitar. Perairan yang tercemar dapat ditelaah dengan mengetahui pola gerakan massa airnya, dinamika perairan tersebut dapat diketahui dengan mengenal parameter-parameter oseanografi perairan yang di (J. I. Pariwono, Bye, \& Lennon, 1986; John I. Pariwono, Ilahude, \& Hutomo, 2005). 
Perairan pantai Tatapaan merupakan bagian dari Teluk Amurang, adalah perairan yang banyak di manfaatkan oleh masyarakat setempat sebagai daerah perikanan tangkap (fishing ground), budidaya (mariculture), transportasi (transportation), dan juga sebagai daerah wisata (tourism). Perairan lautnya sebagian masuk di dalam wilayah Taman Nasional Bunaken yaitu di perairan Popareng yang berbatasan langsung dengan wilayah perairan pantai Bajo.

Berbagai kegiatan tersebut akan menyebabkan peningkatan jumlah bahan pencemar serta pengaruh terhadap kondisi eksisting alamiah pantai. Dengan dasar pemikiran tersebut maka perlu dilakukan kajian kondisi hidro oseanografi dan bathimetri pantai
Tatapaan untuk keperluan perencanaan pengelolaan wilayah pesisir Kabupaten Minahasa Selatan. Tujuan dari penelitian ini adalah mengkaji parameter fisik hidrooseanografi dan bathimetri perairan pantai Tatapaan.

\section{METODE}

Perairan pantai Tatapaan berada di bagian dalam Teluk Amurang yang memanjang dari arah selatan ke utara sepanjang $\pm 5 \mathrm{~km}$ adapun posisi geografis wilayah pesisirnya adalah $1^{0} 16^{\prime} 13.63^{\prime \prime} \mathrm{LU}$ dan 124034'22.79'BT sampai 1016'47.26"LU dan 124032'15.76"BT (Gambar $1)$.

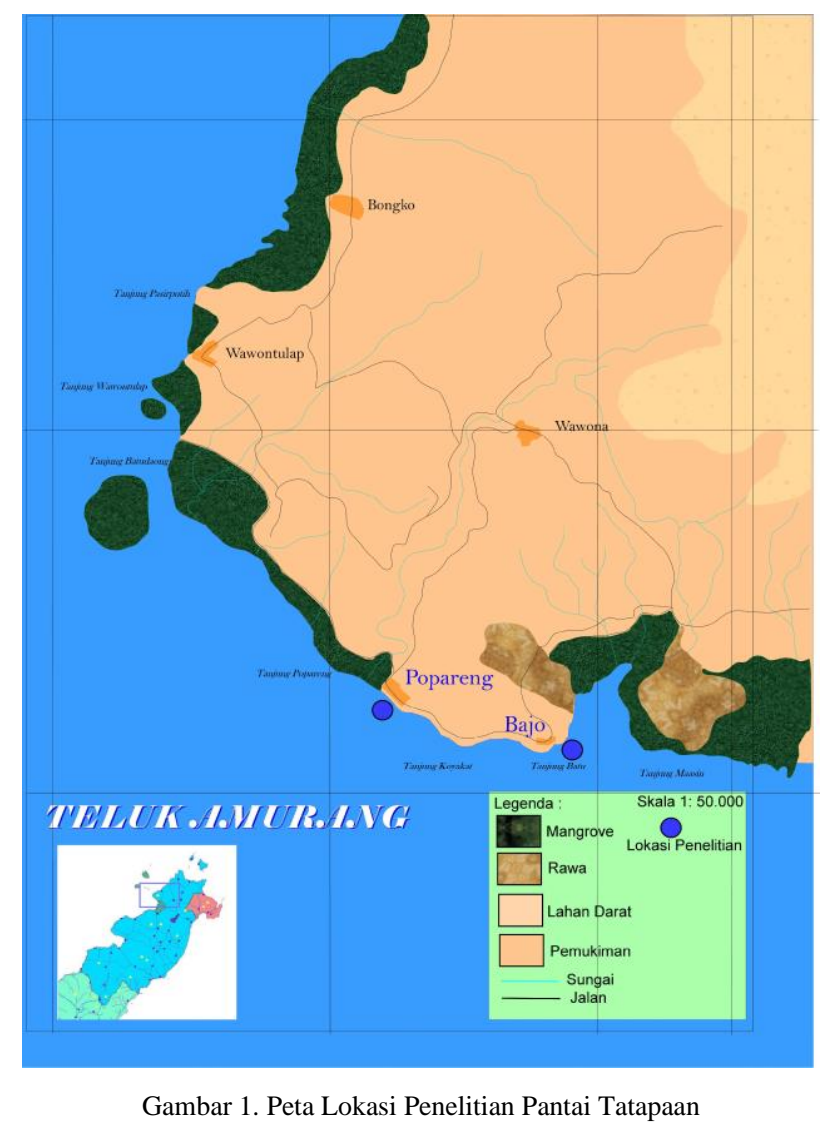

Pengukuran arus laut dan pasang surut dilakukan bersamaan, dimana untuk arus pasang surut dilakukan pengukuran pada titik onshore dan offshore. Pengukuran arus laut digunakan current meter tipe Flow Probe Global Waters 101, dengan sistem computerized dengan mencatat kecepatan maksimum (max velocity) dan kecepatan rata-rata (average velocity) dalam meter/jam (mph). Sedangkan untuk arah arus digunakan floater (pengapung) dengan kompas sebagai penunjuk arah. Pengambilan data arus dilakukan pada dua titik sampling di onshore dan offshore, dengan tiga kedalaman ukur yaitu $0.2 \mathrm{~d}, 0.6 \mathrm{~d}$ dan $0.8 \mathrm{~d}$ dimana d adalah kedalaman ukur (Bapeer \& Bakir, 2018). Analisis data arus adalah menghitung arus maksimum berdasar pada rumus yang di kembangkan oleh (Simatupang, Surbakti, \& Agussalim, 2016) yaitu:

$$
\text { U_max }=A \sqrt{ }(g / d)
$$


dimana: $u_{\max }=$ kecepatan maksimum arus pasut $(\mathrm{m} /$ det $), \quad \mathrm{A}=$ amplitudo pasut, $\mathrm{g}=$ akselerasi karena gravitasi bumi dan $\mathrm{d}=$ kedalaman perairan. Sebaran arus permukaan di gunakan metode langrangian (Nugraha, Subakti, Risandi, \& Mbay, 2014) yaitu dengan melakukan pengukuran arus pada setiap titik ukur (sampling) yang di tetapkan terlebih dahulu dengan menggunakan GPS type Garmin C60. Pemetaan dispersi arus permukaan (surface current dispersion) digunakan perangkat lunak Surfer v15 dengan metode kriging.

Pengamatan pasang surut laut dilakukan 14 dan 29 hari bulan (piantan-lunar days) secara terus menerus, data-data hasil pengukuran disajikan dalam bentuk komponen harmonik pasang surut yang di analisis dengan metoda admiralty (Fadilah, Suripin, \& Sasongko, 2014). Penerapan metoda admiralty ini dimaksudkan untuk observasi data-data harian pendek. Datadata harian pasang surut kemudian di analisa konstanta harmonik pasang surut dimodelkan dengan persamaan (Fadilah et al., 2014):

$$
\mathrm{y}_{\mathrm{b}}=\mathrm{A}_{\mathrm{b}} \cos (\omega \mathrm{t}+\phi)
$$

Dengan $\mathrm{y}_{\mathrm{b}}=$ tinggi muka air laut saat $\mathrm{t}, \mathrm{A}_{\mathrm{b}}$ $=$ amplitudo pasut, $\omega=$ kecepatan sudut $(2 \pi \mathrm{f}, \mathrm{t}=$ waktu dan $\phi=$ keterlambatan fase. Analisa tipe pasut (nisbah formzahl) di lokasi penelitian digunakan persamaan (Korto, Jasin, \& Mamoto, 2015):

$$
\mathrm{F}=\left(\mathrm{K} \_1+\mathrm{O} \_1\right) /\left(\mathrm{M} \_2+\mathrm{S} \_2\right)
$$

Dimana, berdasarkan nisbah formzahl dapat dikelompokkan kedalam tipe pasut dengan bentuk nilai $0<\mathrm{F}<0,25$ adalah pasut harian ganda murni, $0.25<\mathrm{F}<1.5$ campuran berganda, $1.5<\mathrm{F}<3$ campuran tunggal dan $\mathrm{F}>$ tunggal murni. Adapun pengamatan pasang surut di gunakan rambu ukur (tide pole) dengan skala $\mathrm{cm}$.

Pemeruman atau batimetri, prosedur pelaksanaanya dengan mengikuti $I H O$ standarts for Hydrographics Survey (Febrianto, Hestirianoto, \& Agus, 2016). Pelaksanaan pemeruman di gunakan video-sounder merek eagle 128, sedangkan posisi geografis menggunakan GPS Garmin C60 dengan proyeksi Universal Transverse Mercator (UTM) dan ellipsoid WGS 84. Disain lajur pemeruman (sounding line), dibuat sedemikian rupa sehingga memudahkan pada saat pengukuran kedalaman di titik-titik fix perum, biasanya yang di gunakan dalam lajur sounding adalah arah tegak lurus pantai. Oleh (Febrianto et al., 2016), untuk hasil pengukuran garis pantai (shoreline map), koordinat titik fix serta kedalaman terukur (h-ukur), kedalam transducer ( $\mathrm{h}$-transducer), pasut ( $\mathrm{h}$-pasut) disajikan dalam bentuk table. Kedalaman terukur dihitung dengan bilangan koreksi pasang dan transducer yang di set sedalam $30 \mathrm{~cm}$ selama pengukuran berlangsung. Adapun harga kedalaman terkoreksi adalah:

$$
\mathrm{H}_{\text {plot }}=\mathrm{h}_{\text {ukur }}+\mathrm{h}_{\text {transducer }}-\mathrm{h}_{\text {pasut }}
$$

\section{HASIL DAN PEMBAHASAN \\ Kondisi Arus Laut di Pantai Tatapaan}

Pengukuran arus laut di lakukan pada 20 titik sampel seperti yang ditunjukan pada tabel 1 di bawah ini, lokasi pengambilan data arus laut tersebar di sepanjang pantai Tatapaan.

Tabel 1. Data Distribusi Arus Laut

\begin{tabular}{llll}
\hline Posisi Geografis & & \multicolumn{2}{l}{ Kecepatan Arus } \\
\hline$X$ & $Y$ & $v(\mathrm{~m} / \mathrm{d})$ & Arah \\
\hline 670867.297 & 141374.191 & 0.03 & 320 \\
671168.563 & 141294.612 & 0.04 & 10 \\
671509.618 & 141129.768 & 0.01 & 45 \\
670850.245 & 141152.505 & 0.08 & 30 \\
671171.405 & 141186.611 & 0.07 & 320 \\
671484.039 & 140976.293 & 0.08 & 300 \\
671751.199 & 141018.925 & 0.06 & 20 \\
671719.935 & 140771.660 & 0.07 & 360 \\
672140.570 & 140828.503 & 0.05 & 20 \\
672146.254 & 140618.185 & 0.50 & 30 \\
672453.204 & 140555.659 & 0.70 & 120 \\
672470.257 & 140368.078 & 0.30 & 230 \\
672802.785 & 140558.501 & 0.08 & 330 \\
672603.837 & 140217.446 & 0.04 & 300 \\
673530.370 & 140513.027 & 0.03 & 340 \\
673538.896 & 140254.393 & 0.06 & 60 \\
673928.267 & 140549.974 & 0.07 & 90 \\
673922.583 & 140154.919 & 0.90 & 90 \\
674184.059 & 140834.187 & 0.10 & 300 \\
674400.061 & 140177.656 & 0.30 & 300 \\
\hline
\end{tabular}

Sumber: Data Lapangan 2018

Dari tabel 1, dapat di lihat bahwa pada titik pengukuran 17 atau pada posisi geografis 673922.583 utara dan 140154.919 timur, kecepatan arus terukur maksimum adalah adalah $0.9 \mathrm{~m} /$ det dengan arah $90^{\circ}$. sebaliknya pada titik pengukuran 3 dengan posisi geografis 671509.618 utara dan 141129.768 timur, kecepatan arus terukur minimum adalah 0.01 $\mathrm{m} /$ det dengan arah $45^{\circ}$. Distribusi arus permukaan pada lokasi penelitian arah dan 
kecepatannya bervariasi menurut titik-titik pengukuran, pada gambar 2, hasil analisis perangkat lunak Surfer v15, dengan gridding method: natural neighbor, terlihat bahwa arus yang berada di perairan popareng dominan dipengaruhi oleh aliran massa air dari luar teluk Amurang, sedangkan arus yang masuk dari perairan Bajo akan membentur tanjung Koyakat dengan massa aliran akan berputar ke arah timur tidak masuk ke perairan Popareng akan tetapi keluar menuju teluk Amurang. Pada sisi yang lain, aliran arus laut menuju perairan Bajo dari tanjung Koyakat (arus dari timur ke barat), kondisi ini menunjukkan adanya coastal circulation cell, yang mana pada setiap bilik- bilik pelataran daerah pantai (coastal shore platform) memiliki segmen-segmen, ini dapat di lihat pada peta distribusi arus permukaan terbagi ke dalam tiga (3) segmen sirkulasi pantai yaitu : segmen dari muara sungai popareng sampai tanjung koyakat, segmen yang kedua dari tanjung koyakat sampai dengan tanjung Bajo, sedangkan segmen yang ketiga adalah sirkulasi pantai yang terjadi di lesuk Bajo. Hal ini, merupakan fenomena tersendiri bahwa dalam luasan areal sempit $( \pm 5$ $\mathrm{km})$, pelataran pantai menunjukkan adanya dinamika fluida yang bervariasi menurut pola arus yang terjadi. Selanjutnya untuk arus maksimum, yang adalah merupakan perbandinan dari amplitudo pasang surut dilokasi studi (A), gaya grafitasi bumi (g) dan kedalaman ukur (d).

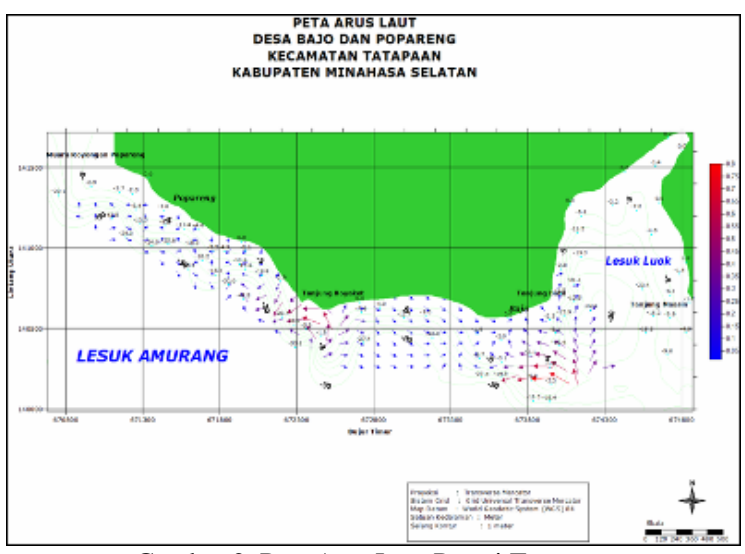

Gambar 2. Peta Arus Laut Pantai Tatapaan

Tabel 2. Kecepatan Arus Laut

\begin{tabular}{lllllll}
\hline \multirow{2}{*}{ Lokasi } & \multicolumn{6}{l}{ Kecepatan Arus $(\mathrm{m} /$ det $)$} \\
\cline { 2 - 7 } & 0.2 & 0.6 & 0.8 & 0.2 & 0.6 & 0.8 \\
\cline { 2 - 7 } & 0.50 & 0.45 & 0.53 & 0.40 & 0.30 & 0.60 \\
\hline $\begin{array}{l}\text { Bajo dan } \\
\text { Popareng }\end{array}$ & & & & & & \\
\hline Sumber : Data Lapangan 2018 & & & &
\end{tabular}

\section{Kondisi Pasut di Pantai Tatapaan}

Kondisi pasang surut di pantai Tatapaan menunjukkan pola yang sama dengan pantaipantai lainnya di pesisir Sulawesi Utara yaitu tipe campuran condong ke harian ganda. Elevasi pasang surut yang terjadi di analisis dengan menggunakan metode konstanta harmonik untuk mendapatkan 10 konstanta yang umum di pakai di dalam menganalisis tipe pasang surut. Hasil analisis harmonik pasang surut, dapat di tunjukkan pada table 3 berikut ini:

Tabel 3. Analisa Komponen Harmonik Pasut

Komponen Pasang Surut $(\mathrm{cm})$

\begin{tabular}{llllllllll}
$S_{0}$ & $M_{2}$ & $S_{2}$ & $N_{2}$ & $K_{1}$ & $O_{1}$ & $M_{4}$ & $M_{S 4}$ & $K_{2}$ & $P_{1}$ \\
\hline
\end{tabular}

$\begin{array}{llllllllll}1116,3 & 29,2 & 43,1 & 9,6 & 9,0 & 20,2 & 0,5 & 0,8 & 9, & 3,0\end{array}$

Sedangkan, nisbah formzahl adalah:

$$
\mathrm{F}=(9.0+20.2) /(29.2+43.1)=0.40
$$

Pantai Tatapaan memiliki tipe pasang surut bersifat campuran berganda $(0.25<\mathrm{F}<$ 1.5), berarti bahwa dalam satu hari terjadi dua kali pasang dan dua kali surut. Hasil pengukuran pasang surut dapat di lihat pada gambar 3 berikut ini.

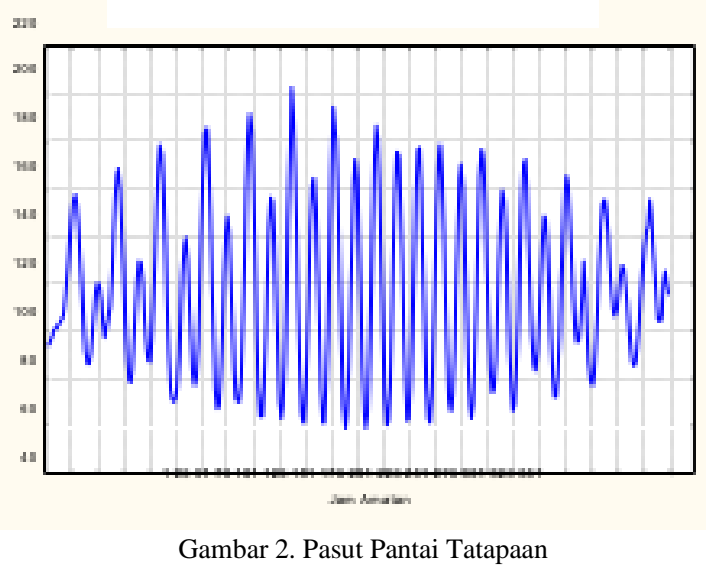

Tunggang pasut atau tinggi pasut yang terbaca pada setiap pengamatan menunjukan perebedaan dari hari ke hari dan ini berlaku pada semua tempat (perairan), keadaan ini disebut ketidaksamaan (inequality). Ketidaksamaan tunggang pasut ini di sebabkan oleh beberapa faktor yaitu (Dishidros dalam Tilaar 1993): perubahan lintang bulan terhadap bumi, perubahan fase (umur) bulan, perubahan jarak antar bumi dan bulan dan perubahan deklinasi dari bulan.

\section{Batimetri di Pantai Tatapaan}

Hasil survey bathimetri di pantai Tatapaan 
dengan di lakukan sounding dengan panjang pantai $\pm 5 \mathrm{~km}$, di mulai dari sungai popareng kemudian dilakukan pemeruman dengan menggunakan lajur yang sudah ditentukan terlebih dahulu, pada setiap titik fiks (titik tetap) diambil koordinat geografi (x dan y) bersamaan dengan titik kedalaman (z). Pemeruman, sepanjang lajur yang sudah ditetapkan bolak balik dengan kedalaman maksimum adalah \pm 20 $\mathrm{m}$. Dari hasil analisis kemiringan lereng di dapat bahwa variasi lereng di pantai Tatapaan antara $1.28 \%-14.61 \%$, terdefinisikan sebagai pantai landai sampai curam. Dari 48 profil pantai yang diambil sebagai transek untuk pengukuran profil pantai, sebanyak 47 profil pantai teridentifikasi sebagai pantai curam sedangkan satu profil pantai yang berada di pantai Bajo teridentifikasi sebagai pantai landai. Hal ini di tandai dengan adanya terumbu yang menjorok kearah laut. Variasi morfologi pantai Tatapaan adalah merupakan proses geologi yang panjang di mana perubahan bentuk bentang alam pesisir sangat di pengaruhi oleh faktor-faktor hidrodinamika air laut. Di pantai Popareng banyak terdapat batuan magmatik terhamapar di sebagian pantainya bercampur dengan sedimen pasir (coasrse sand). Mendandakan bahwa pengaruh daratan memiliki peran terhadap perubahan morfologi pantai.

\begin{tabular}{|c|c|c|}
\hline Nama Profil & Kemiringan (\%) & Keterangan \\
\hline Section Popareng - 1 & 5.42 & Curam \\
\hline Section Popareng - 2 & 4.69 & Curam \\
\hline Section Popareng -3 & 6.82 & Curam \\
\hline Section Popareng -4 & 6.69 & Curam \\
\hline Section Popareng - 5 & 7.46 & Curam \\
\hline Section Popareng -6 & 7.62 & Curam \\
\hline Section Popareng - 7 & 8.76 & Curam \\
\hline Section Popareng -8 & 9.99 & Curam \\
\hline Section Popareng - 9 & 10.73 & Curam \\
\hline Section Popareng -10 & 8.28 & Curam \\
\hline Section Popareng - 11 & 8.18 & Curam \\
\hline Section Popareng - 12 & 11.04 & Curam \\
\hline Section Popareng - 13 & 8.75 & Curam \\
\hline Section Popareng - 14 & 9.85 & Curam \\
\hline Section Popareng - 15 & 9.41 & Curam \\
\hline Section Popareng - 16 & 10.13 & Curam \\
\hline Section Popareng - 17 & 5.55 & Curam \\
\hline Section Popareng - 18 & 5.26 & Curam \\
\hline Section Bajo - 1 & 7.11 & Curam \\
\hline Section Bajo - 2 & 7.84 & Curam \\
\hline Section Bajo - 3 & 11.12 & Curam \\
\hline Section Bajo - 4 & 12.58 & Curam \\
\hline Section Bajo - 5 & 12.75 & Curam \\
\hline Section Bajo - 6 & 9.26 & Curam \\
\hline
\end{tabular}

\begin{tabular}{|c|c|c|}
\hline Section Bajo - 7 & 6.76 & Curam \\
\hline Section Bajo - 8 & 5.88 & Curam \\
\hline Section Bajo-9 & 5.80 & Curam \\
\hline Section Bajo - 10 & 5.04 & Curam \\
\hline Section Bajo - 11 & 4.55 & Curam \\
\hline Section Bajo - 12 & 3.67 & Curam \\
\hline Section Bajo - 13 & 2.96 & Curam \\
\hline Section Bajo - 14 & 4.86 & Curam \\
\hline Section Bajo - 15 & 13.46 & Curam \\
\hline Section Bajo - 16 & 10.57 & Curam \\
\hline Section Bajo - 17 & 15.82 & Curam \\
\hline Section Bajo - 18 & 14.61 & Curam \\
\hline Section Bajo - 19 & 10.00 & Curam \\
\hline Section Bajo - 20 & 4.99 & Curam \\
\hline Section Bajo - 21 & 2.84 & Curam \\
\hline Section Bajo - 22 & 1.28 & Landai \\
\hline Section Bajo - 23 & 2.37 & Curam \\
\hline Section Bajo - 24 & 3.45 & Curam \\
\hline Section Bajo - 25 & 5.33 & Curam \\
\hline Section Bajo - 26 & 6.93 & Curam \\
\hline Section Bajo - 27 & 4.51 & Curam \\
\hline Section Bajo - 28 & 4.68 & Curam \\
\hline Section Bajo - 29 & 3.70 & Curam \\
\hline
\end{tabular}

\section{KESIMPULAN}

Kondisi hidro-oseanografi pantai Bajo Popareng adalah merupakan satu kesatuan dengan kondisi yang ada di Teluk Amurang, dari hasil pengukuran dan analisis data di temukan bahwa arus laut maksimum dengan kecepatan $0.60 \mathrm{~cm} /$ det di kedalaman $0.8 \mathrm{~d}$ didaerah offshore. Sedangkan, distribusi arus permukaan terukur bervariasi antara: $0.01-0.9 \mathrm{~m} / \mathrm{det}$ yang di ambil dari 18 titik disekitar perairan Bajo dan Popareng. Tipe pasang - surut yang terukur dari analisa nisbah Formzhal adalah 0.40, adalah merupakan tipe pasang surut semi-diurnal yang diartikan bahwa dalam satu hari siklus pasang surut terjadi dua kali pasang (air naik) dan dua kali air surut (air turun). Selanjutnya, dari hasil survey bathimetri sepanjang $\pm 5 \mathrm{~km}$ panjang garis pantai dari desa Bajo sampai dengan desa Popareng di tunjukkan dengan variasi kemiringan lereng antara: $1.28-15.82 \%$ yang didefinisikan sebagai pantai landai sampai curam dari 49 transek yang di ambil sebagai profil contoh.

\section{DAFTAR PUSTAKA}

A. Pratikto, W. (2003). Kebijakan Penataan Pesisir dan Pulau-pulau Kecil di Indonesia. Alami: Jurnal Teknologi Reduksi Risiko Bencana. 
Bapeer, G. B., \& Bakir, H. B. (2018). Applying Ground Penetrating Radar Current Meter Devices for Measuring Lesser Zab River Discharge in Taqtaq Area, Iraq. International Iraqi Conference on Engineering Technology and Its Applications, IICETA 2018. https://doi.org/10.1109/IICETA.2018.8458 091

Fadilah, Suripin, \& Sasongko, D. P. (2014). Menentukan Tipe Pasang Surut dan Muka Air Rencana Perairan Laut Kabupaten Bengkulu Tengah Menggunakan Metode Admiralty. Maspari.

Febrianto, T., Hestirianoto, T., \& Agus, S. B. (2016). Pemetaan Batimetri Di Perairan Dangkal Pulau Tunda, Serang, Banten Menggunakan Singlebeam Echosounder. Jurnal Teknologi Perikanan Dan Kelautan. https://doi.org/10.24319/jtpk.6.139-147

Korto, J., Jasin, M. I., \& Mamoto, J. D. (2015). Analisis pasang surut di pantai nuangan (desa iyok) boltim dengan metode admiralty. Sipil Statistik.

Mujio. (2016). Model Perencanaan Tata Ruang Pesisir Dengan Pendekatan Keterkaitan Daratan Dan Perairan Pesisir.

Nugraha, R. B. A., Subakti, H., Risandi, J., \& Mbay, L. ode N. (2014). 2D Numerical Model of Ocean Current in Nusa Penida, Bali. Jurnal Kelautan Nasional.

Paimin, Pramono, I. B., Purwanto, \& Indrawati, D. R. (2012). Sistem Perencanaan Pengelolaan Daerah Aliran Sungai. In Dynamical systems with applications using MATLAB.

https://doi.org/10.1017/CBO97811074153 24.004

Pariwono, J. I., Bye, J. A. T., \& Lennon, G. W. (1986). Long-period variations of sea-level in Australasia. Geophysical Journal of the Royal Astronomical Society. https://doi.org/10.1111/j.1365246X.1986.tb04545.x

Pariwono, John I., Ilahude, A. G., \& Hutomo, M. (2005). Progress in oceanography of the Indonesian seas a historical perspective. Oceanography. https://doi.org/10.5670/oceanog.2005.04

Rahayu, S., Piarsa, I. N., \& Buana, P. W. (2016). Sistem Informasi Geografis Pemetaan Daerah Aliran Sungai Berbasis Web. Lontar Komputer : Jurnal Ilmiah Teknologi Informasi. https://doi.org/10.24843/lkjiti.2016.v07.i0 2.p01

Simatupang, C. M., Surbakti, H., \& Agussalim, A. (2016). Analisis Data Arus di Perairan Muara Sungai Banyuasin Provinsi Sumatera Selatan. Maspari Journal, UNSRI.

Sudaryono. (2002). Pengelolaan Daerah Aliran Sungai (DAS) Terpadu. Jurnal Teknologi Lingkungan. 